\title{
Relationship of Individual Factors and HRM Practices on Employee Retention in Private Banking Sector of Bangladesh
}

\author{
[SK. Tasthekur Hossain Kowshik, Samia Shabnaz, Stanley Sumon Rodrick]
}

\begin{abstract}
Bangladesh is growing fast. The competition forced the organizations to focus on high quality service for which retaining valuable and skilled workforce is important. The organizations are focusing more on designing customized retention strategies as there is varying relationship with individual factors and the HRM practices. Recent research initiatives concentrated on the causes of employee turnover; whereas this research focused on the relationship of individual employee's aspects like gender, years of experience and the number of banks they have worked for with the HRM practices (Compensations \& Benefits, Career advancement opportunity, Job security, Work place environment, Organization growth and reputation, Relation between top management and employee). The nonprobability purposive sampling was used to select 100 respondents. Selfdeveloped questionnaire using Likert Scale was utilized for data collection. Crosstab, frequency table were used to generate results with the help of SPSS Ver. 20. It has been observed that the priority of the HRM strategies differs based on different individual factors of the employees. This study will help the banks to design appropriate retention strategy according to the preference of the diverse employees.
\end{abstract}

Keywords - factors, retention, job experience, bank.

\section{Introduction}

The banking industry of Bangladesh is changing rapidly due to the change in customer demand. Currently the industry consists of a central bank (Bangladesh Bank), 6 state-owned commercial banks (SCBs), 2 state-owned development financial institutions (DFIs), 39 private commercial banks (PCBs) and 9 foreign commercial banks (FCBs). At the end of June 2016, the total number of bank branches increased from 9397 to 9453 (Bangladesh Bank Annual Report 2015-2016, 2016).

SK. Tasthekur Hossain Kowshik

American International University- Bangladesh Bangladesh

Samia Shabnaz

American International University- Bangladesh Bangladesh

Stanley Sumon Rodrick

American International University- Bangladesh

Bangladesh
Private Commercial Banks captured a large portion of the market share in terms of both industry assets and deposits (Bangladesh: Selected Issues, 2007). Profitability, measured by return on asset and return on equity, has been negative for the state-owned banks (SCBs) on the other hand for private commercial banks, though these indicators are positive (The Daily Star, 2017). As the competitiveness of the market is increasing substantially, the retail banking is focusing on service quality and employee retention by satisfying their skilled employees to gain a competitive advantage.

As nature of work in the banking sector is changing rapidly, the factors that influence employee retention are also shifting. Excessive employee turnover may cause a key barrier to high quality service so it is necessary to identify the reasons of employee turnover and what the employer can do to retain the best (Branham, 2005). The banks invests a lot on their employees through job analysis, recruitment \& selection, training, development and a healthy compensation package to ensure retention. Some external factors as well as some organizational factors and personal characteristics and employee's own reaction to his/her job affect the turnover intention (Knowles, 1964).

To continue to exist in a very competitive environment, the banks need to design effective human resource (HR) practices that encourage the high performance of employees. Several research have been done on the impact of HRM practices on employee satisfaction but very few researchers concentrated on the factors like gender, work experience and number of organization the employees have worked and their impact on employee retention. So this research focused on understanding the relationship of the individual factors with the HRM practices (Compensations \& Benefits, Career advancement opportunity, Job security, Work place environment, Organization growth and reputation, Relation between top management and employee) so that organizations can develop effective strategy for retention. The rest of this paper is organized with a brief literature review on the factors influencing turnover intention, the research methodology and the results of data. Finally the paper concluded with major finding and indicated some future research directions.

\section{Review of Related Literature}

Employees are valuable for the organization as they are intangible and not replicable which can be a source for the organization's sustainable competitive advantage (Meaghan $\&$ Nick 2002). Several researchers concentrated on the issue of turnover because turnover has some significant effects on organizations (DeMicco \& Giridharan 1987; 
Dyke \& Strick 1990; Cantrell \& Saranakhsh 1991; Denvir \& Mcmahon 1992). Many researchers argue that if the organizations don't have the capability to manage high turnover rates than it might have negative effects on profitability (Hogan 1992; Wasmuth \& Davis 1993; Barrows 1990). To be competitive, the firms must retain their competent and motivated employees (Mahmud and Idrish, 2011). So the organization must concentrate on the factors that they have control over influencing retention.

Few researches have been done on the context of Bangladesh. Mahmud and Idrish (2011) conducted an empirical study and evaluated six Human Resource (HR) practices (realistic job information, job analysis, work family balance, career development, compensation and supervisor support) and their likely impact on the Employee Intention to Leave (EIL) in the Bangladeshi Banks. Finding of the study indicated that work family balance and employee intention to leave was positively correlated and compensation and job analysis are the most critical HRM practices to be implemented by banks to reduce EIL. Similarly Newaz, et.al, (2007) also carried out research on banking sector of Bangladesh and found that employees said that the most important factor for leaving the organization is because their work is unappreciated and not recognized by the organization. In contrast Tanchi (2015) portrayed that some factors such as unattractive pay packages, lack of training and development, partiality and lack of career development influences employee to leave the job but some factors do not influence employee turnover though it seems to be important such as long working hours, lack of job security and work life imbalance etc. Employees with high satisfaction trust that their organization has a tremendous future and in the end, it would care give the necessary credit to their quality work which increases the commitment towards the organization (Eshiteti et al., 2013). According to Samuel and Chipunza (2009), for public and private organizations job security was found to be ominously influencing factor in employee retention. Providing good working conditions is essential to satisfy the needs of its employees for increase efficiency, effectiveness, productivity and job commitment of employees (Raziq and Maulabakhsh, 2015). It has been found that brand names of organizations have meaningfully effect the decision of employees to join as well as stay in the organization and with actual employer branding leads to competitive advantage helps employees adopt company values, assists in employee retention (Sokro, 2012).

\section{Methodology of the Study}

The research was conducted on private commercial banks of Bangladesh by concentrating on the HRM practices (compensation, career growth, employee relation with management, stress, work environment, job security) affecting Employee's retention. Both primary and secondary data has been collected. The sample of the study was taken from the five different banks (Midland Bank Limited Meghna Bank Limited, BRAC Bank Limited, Social Islami Bank Ltd, Pubali Bank Limited) in Dhaka City which was randomly selected. As total population is not accessible the study implemented non-probability convenience sampling and 100 employees were taken as sample size. To collect primary data a self-designed questionnaire with 29 questions was used and distributed to different managerial levels. The data analysis was done using SPSS version 20 and Crosstab, frequency table was used to generate results.

\section{Discussion}

\section{1) Reliability Test}

As the questionnaire used for data collection was designed rather than adopted from an existing research, a reliability test was thought necessary. The Cronbach Alpha testing was used as it is the most well accepted reliability test tools applied by social researcher (Sekaran, 2003). The closer Cronbach's Alpha is to 1.0, the higher is the internal consistency reliability. Cronbach measures indicates that if the reliability is more than 0.8 than it is considered to be good. The questionnaire used in this research is considered acceptable as its value mentioned in Table I are more than 0.80 .

TABLE I. RELIABILITY STATISTICS

\begin{tabular}{|l|l|}
\hline Cronbach's Alpha & N of Items \\
\hline .922 & 29 \\
\hline
\end{tabular}

The demographic profile of the respondent is given in the table II below. Here it can be seen that more than half of the respondents (59\%) are male and rest is female (41\%). According to managerial level majority belongs to middle level $(51 \%)$. It is indicated that a large number of respondents $(45 \%)$ have $1-2$ years of experience in their current job whereas the respondents with total experience of 1-2 years is only $16 \%$. The profile also indicates that majority $(56 \%)$ has more than 5 years of job experience. On the other hand $43 \%$ of the respondents have worked for at least two organizations and $28 \%$ worked for more than two organizations.

TABLE II. DEMOGRAPHIC PROFILE

\begin{tabular}{|l|l|l|}
\hline \multirow{3}{*}{ Gender } & Male & $59 \%$ \\
\cline { 2 - 3 } Management Level & Female & $41 \%$ \\
\hline \multirow{3}{*}{ Experience in Current Job } & Top Level & $14 \%$ \\
\cline { 2 - 3 } & Middle level & $51 \%$ \\
\cline { 2 - 3 } & Entry Level & $35 \%$ \\
\hline \multirow{3}{*}{ Job Experience } & $1-2$ years & $45 \%$ \\
\cline { 2 - 3 } & $3-4$ years & $36 \%$ \\
\cline { 2 - 3 } & $5+$ years & $19 \%$ \\
\hline \multirow{3}{*}{ Number of Organization Worked } & $1-2$ years & $16 \%$ \\
\cline { 2 - 3 } & $3-4$ years & $28 \%$ \\
\cline { 2 - 3 } & $5+$ years & $56 \%$ \\
\cline { 2 - 3 } & 1 & $29 \%$ \\
\cline { 2 - 3 } & 2 & $3+$ \\
\hline
\end{tabular}

Table III indicates the relationship of gender with the Human Resource Management Practices. It is evident that there is no significant difference in opinion regarding compensation, career growth, stress, work environment and job security based on gender. The relationship of gender only exists regarding the employee relations with management. Majority of the male employees are in favor of the reasonability of the amount of work and clarity of the supervisor's expectation than that of female. The significance of these relationships is also visible in the table III. 
TABLE III. RELATIONSHIP OF GENDER WITH THE HuMAN RESOURCE MANAGEMENT PRACTICES

\begin{tabular}{|l|c|}
\hline \multicolumn{1}{|c|}{ HRM Practices } & Sig \\
\hline Reasonability of expected amount of work & $\mathrm{p}=0.013$ \\
\hline Clarity of Supervisor's expectation & $\mathrm{p}=0.022$ \\
\hline
\end{tabular}

Table IV portrays that relationship exists between the years of experience in current job and the Human Resource Management Practices. It is evident that employees with less experience in current job is more satisfied than the more experienced people in current job and this relationship is significant. On the other hand employees with less experience in current job are more affected by the perception of organizational profitability increase than the more experienced employees. The relationship is indicated by the p-value.

TABLE IV. RELATIONSHIP OF EXPERIENCE IN CURRENT JOB WITH THE Human Resource Management PRACTICES

\begin{tabular}{|l|r|}
\hline \multicolumn{1}{|c|}{ HRM Practices } & Sig \\
\hline Amount of Bonus & $\mathrm{p}=0.022$ \\
\hline Perception of organizational profitability increase & $\mathrm{p}=0.006$ \\
\hline
\end{tabular}

In Table $\mathrm{V}$ the result shows that employees with more experience in the banking industry are favoring more their organization's concentration regarding their career advancement policy than less experienced employees. On the other hand, more experienced people are less satisfied about the process used to determine promotions. Moreover, employees with the medium level of experience in the industry feels that their organizations are less concern about treating them as part of the organization. More experienced employees feels more secured in the organization. Employees who have recently joined the organization or have less working experience they are not satisfied with their organization regarding cooperation on the teamwork. Employees with more experience in the banking industry are less concerned about organizational reputation. Regarding the issue of supervisor's expectation from the employees regarding their job performance, there is relationship with job experience. Less experienced employees are clearer about the job expectation than the experienced employees. Finally, supervisor's regular evaluation is more important for the less experienced employees. The relationship of employees experience with the HRM practices are indicated in the Chi-Square Test of table V.

TABLE V. RELATIONSHIP OF THE YEARS OF EXPERIENCE WITH THE HUMAN RESOURCE MANAGEMENT PRACTICES

\begin{tabular}{|l|c|}
\hline \multicolumn{1}{|c|}{ HRM Practices } & Sig \\
\hline Organizations concentration on employee's career advancement & $\mathrm{p}=0.037$ \\
\hline Process used to determine promotions & $\mathrm{p}=0.022$ \\
\hline Organizational treat employees as part of the organization & $\mathrm{p}=0.013$ \\
\hline Workplace security for the employees & $\mathrm{p}=0.010$ \\
\hline Existence of cooperation and teamwork in the organization. & $\mathrm{p}=0.009$ \\
\hline The organization's reputation is impotent & $\mathrm{p}=0.021$ \\
\hline $\begin{array}{l}\text { Clarity of supervisor's expectation } \\
\text { regarding their job performance }\end{array}$ & $\mathrm{p}=0.044$ \\
\hline $\begin{array}{l}\text { Supervisor's regular evaluation of } \\
\text { employees work performance }\end{array}$ & $\mathrm{p}=0.048$ \\
\hline
\end{tabular}

The relationship with the number of organization the employee worked for and HRM practices are indicated in Table VI. It is evident that the relationship exists between the number of organization worked and the satisfaction related to the amount of bonus. So those who have experience in two or more organizations they are more satisfied about the amount of bonus than others. On the other hand, the perception about the fairness of the process to determine the annual raise is related with the number of organizational experience. The employees with two organizational experiences have less favorable perception about the fairness of the process to determine the annual raise than others. Employees who have worked for less organization have more dissatisfaction regarding the steps taken by their organization to maximize their career potential. This relation is significant which is evident in the Chi-square test. The employees with two organizational experiences less favors the organizational assistance for gaining more working experience in their current job areas than the employees with one or more than two organizations experience. There is significant relationship between the number of organization worked and the perception regarding career progression opportunities availability in their organization. Employees with two organizational experiences have less favorable perception regarding career progression opportunities availability in their organization. It is also evident in the analysis that there is significant relationship with number of organization worked with the perception about the fairness of the process used to determine promotion. The employees with experience in one organization and more than two organization has more favorable perception regarding the fairness of promotion than the employees with experience in two organization. On the other hand organization concern of having long term relationship is more favorable by the employees with more experience in different organization than others and the relationship is significant. It has been found that there is relationship exists between the number of organization employees worked and the perception about the reasonability of firing employees. Employees who have worked for two organizations have less favorable opinion about the reasonability of firing employees than others. Employees who have worked for two organizations have more positive believe regarding their organization job security. The employees who have worked for only one organization have more regular supervisor's evaluation. The relationship is evident in the Chi-Square test.

TABLE VI. RELATIONSHIP OF THE NUMBER OF ORGANIZATION EMPLOYEE WORKED FOR WITH THE HUMAN RESOURCE MANAGEMENT PRACTICES

\begin{tabular}{|l|c|}
\hline \multicolumn{1}{|c|}{ HRM Practices } & Sig \\
\hline Amount of bonus & $\mathrm{p}=0.031$ \\
\hline The process used to determine annual raises & $\mathrm{p}=0.004$ \\
\hline $\begin{array}{l}\text { Organizations concentration on } \\
\text { employee's career advancement }\end{array}$ & $\mathrm{p}=0.031$ \\
\hline Organizational assistance in gaining Work experience & $\mathrm{p}=0.001$ \\
\hline Availability of Career progression opportunity & $\mathrm{p}=0.019$ \\
\hline Process used to determine promotions & $\mathrm{p}=0.030$ \\
\hline $\begin{array}{l}\text { The organization's concern in having a } \\
\text { long term relationship with employees }\end{array}$ & $\mathrm{p}=0.007$ \\
\hline Reasonability of firing employees & $\mathrm{p}=0.000$ \\
\hline Perception regarding job security & $\mathrm{p}=0.001$ \\
\hline $\begin{array}{l}\text { Supervisor's regular evaluation } \\
\text { of employees work performance }\end{array}$ & $\mathrm{p}=0.010$ \\
\hline
\end{tabular}

\section{Findings of Study}

The research concentrated on several individual factors so that the relationship of these factors and the HRM 
practices can be identified to design effective retention strategy for the skilled employees. It is evident that for most of the HRM practices there is no difference in perception based on gender except for reasonability of expected amount of work and clarity of supervisor's expectation. However the experience in the current job has relationship with amount of bonus and perception of organizational profitability increase.

The result also suggests that more experienced people are more concerned about career advancement opportunity, job security and team work. On the other hand more experienced employees are less satisfied about promotion process, concentrate less on organizational reputation, they are less clear about their job responsibility and are less focus on regular supervisor's evaluation. The employees with experience in two organization has less favorable opinion about the fairness of annual raise, career progression opportunity, fairness in process of promotion, fairness in firing employees, regular supervisory evaluation whereas they are more satisfied regarding the bonus amount, job security.

\section{Conclusions}

Employee's retention can be influenced by several variables out of which gender, work experience and number of organizations worked were the concentration of the study. It has been also found that the impact of HR practices vary based on the individual characteristics of the employees. The banks should design their retention programs considering the impact of these individual factors to make the HR more effective. Further research can be done using factor analysis. To conclude it can be said that the banking industry should focus on more customized retention programs for sustainable competitive advantage.

\section{References}

[1] Bangladesh Bank Annual Report 2015-2016. Dhaka: Bangladesh Bank, 2016, p.28

[2] Bangladesh: Selected Issues. International Monetary Fund Country Report. Dhaka: International Monetary Fund, 2007, pp.24-37.

[3] The Daily Star . Banking sector for sustainable growth, 2017.

[4] Branham, L.," The 7 Hidden Reasons Employees Leave", AMACOM, 2005

[5] Knowles, M.C., "Personal and job factors affecting labour turnover" Personnel Practice Bulletin, 20(1): 25-37. 1964

[6] Meaghan, S and Nick, B, "Voluntary turnover: knowledge management-friend or foe?" J. intellect. Cap, vol. 3, no. 3, pp. $303-$ 322,2002

[7] DeMicco, FJ and Giridharan, J, "Managing employee turnover in thehospitality industry", FIU Hosp Rev, 1987, pp. 26-32.

[8] Dyke, TV \& Strick, S, "Recruitment, selection and retention of managers in the hotel and restaurant industry", FIU Hosp Rev, 1990, pp. 1-9.

[9] Denvir A \& McMahon, F , "Labor turnover in London hotels andthe cost effectiveness of preventative measures", Int. J. Hosp.Manage, vol. 11 , no. 2,1992 , pp. 143-54

[10] Hogan, JJ , "Turnover and what to do about it", The Cornell HRA Quarterly, vol. 33, no. 1, 1992, pp. 40-45.

[11] Wasmuth, WJ and Davis, SW, "Managing employee turnover: why employees leave", The Cornell HRA Quarterly, 1993, pp. 11-18.

[12] Barrows, C, "Employee turnover: implications for hotel managers", FIU Hosp Rev, 1990, pp. 24-31.
[13] Mahmud, K. and S. Idrish, "HR practice in Bangladesh: The past and future ahead", World Review of Business Research, 1(2): 71-83, 2011.

[14] Newaz, M. K., "Employee Perception Regarding Turnover Decision In Context of Bangladesh Banking Sector": BRAC University Journal, vol. IV, no. 2, 2007, p.67-74

[15] Tanchi, Khadiza Rahman, "Analyzing the Factors Influencing Employee Turnover in Private Commercial Banks in Bangladesh" Daffodil International University Journal of Business and Economics, Vol. 9, No. 1, PP. 119-130, June, 2015

[16] Eshiteti, S., Okaka, O., Maragia, S., Odera, O. and Akerele, E. (2013). Effects of Succession Planning Programs on Staff Retention. Mediterranean Journal of Social Sciences, 4(6).

[17] Samuel O. Michael and Chipunza Crispen, "Employee retention and turnover: Using motivational variables as a panacea", African Journal of Business Management, Vol.3 (8), pp. 410-415, September, 2009

[18] Raziq, A. and Maulabakhsh, R. (2015). Impact of Working Environment on Job Satisfaction. Procedia Economics and Finance, 23, pp.717-725.

[19] Sokro, E. (2012). Impact of Employer Branding on Employee Attraction and Retention. European Journal of Business and Management, 4(18).

[20] Sekaran, U., "Research methods for business: A skill-building approach.” United Kingdom: Wiley \& Sons Ltd., 2003

About Author (s):

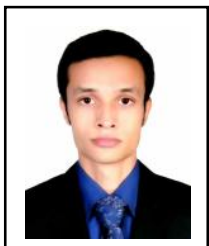

SK. Tasthekur Hossain Kowshik completed his Bachelor in Business Administration from American International University- Bangladesh with major in Human Resource Management and Marketing in 2017. He has worked as a research assistant with the different supervisor. His preferred research areas include human resource management, consumer behavior, and service marketing. Currently, he is working in flydubai as a ground service officer.

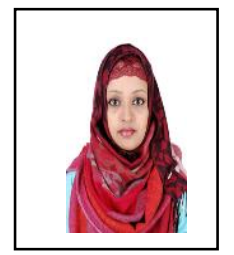

Samia Shabnaz is a Senior Assistant Professor in the Department of Management, American International University-Bangladesh (AIUB). She received Masters in Business Administration from AIUB, in 2008 . She has more than 8 years of experience in teaching several areas of Human Resource Management and her research interest includes microcredit impact assessment, entrepreneurship development initiative, and human resource development. She is currently perusing her M-Phil in Bangladesh University of Professional (BUP).

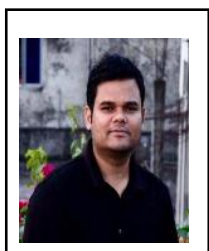

Stanley Sumon Rodrick is serving as an Assistant Professor in the Department of Marketing at the American International University-Bangladesh (AIUB) since January 2010. His research interest includes brand development, rural marketing, agro-based product marketing, consumer behavior, and digital marketing impact on the consumer segments. 